\author{
PART I \\ INAUGURAL CEREMONY \\ $\xi^{\circ}$ \\ GENERAL ASSEMBLY
}

REPORT OF THE EXECUTIVE COMMITTEE 


\section{EXECUTIVE COMMITTEE}

\section{PRESIDENT}

Prof. O. Struve, Astronomical Department, University of California, Berkeley 4, California, U.S.A.

\section{VICE-PRESIDENTS:}

Prof. V. A. Ambartsumian, President of the Academy of Sciences of Armenian S.S.R., Erevan, Armenia, U.S.S.R.

Dr A. Couder, Astronome de l'Observatoire de Paris, Paris-I4e, France.

Prof. E. RybKa, Director of the Astronomical Observatory of the University of Wrockaw, Pologne.

Prof. P. Swings, Directeur de l'Institut d'Astrophysique de l'Université de Liège, Cointe-Sclessin, Liège, Belgique.

Prof. R. v. D. R. Woolley, Director of the Commonwealth Observatory, Mount Stromlo, Canberra, A.C.T., Australia.

GENERAL SECRETARY:

Prof. P. Tн. Oosterhoff, University Observatory, Leiden, Netherlands. 


\title{
INAUGURAL CEREMONY
}

\author{
29 August, 10.00
}

THE Inaugural Ceremony took place in the Ambassador Cinema in Dublin, in the presence of His Excellency the Prime Minister of Eire, of MrE. de Valéra, T.D., Rt Rev. MgrDr P. de Brún, Chairman of Council, Dublin Institute for Advanced Studies, the Ministers for Education and External Affairs and many other authorities, among them many representatives of the Diplomatic Corps in Dublin.

Addresses of welcome were given by: Mr J. A. Costello, S.C., T.D., An Taoiseach, by Mr E. de Valéra, T.D., by Rt Rev. Mgr Dr P. de Brún, by Prof. H. A. Brück, Director of the Dunsink Observatory, and by Prof. O. Struve, President of the International Astronomical Union.

\section{Address by Mr J. A. Costello, Taoiseach}

Cúis mór-áthais dom inniu fáilte a chur, thar ceann Rialtas agus muintir na hÉireann, romhaibh uile go léir a tháinig anseo ag freastal ar an Naoú Comhdháil den Aontas Eadarnáisiúnta Réalteolaíochta. Chuir an tAontas comaoin orainn nuair a ghlacadar, ag an gComhdháil deiridh a bhí acu sa Róimh, le cuireadh chun an Chomhdháil seo a thionól in Eirinn. Is mór an onóir dúinn an oiread sin toscairí cáiliúla a bheith annseo inár measc. Tá súil agam go n-éireoidh go geal leis an gComhdháil.

Sílim gurb í seo an Chomhdháil Eolaíochta Eadarnáisiúnta is mó a tionóladh riamh sa chat hair seo: deirtear liom go bhfuil os cionn ocht gcéad cuairteoiri ar fad againn ó bhreis agus dathad tíortha ar fud an domhain. Is dócha gurb é seo an chéad uair in Érinn ag bhur bhfurmhór agus ba mhaith liom go mbeadh fhios agaibh uile gur ' fosgailte fáilteach an áit sin Éire', mar adúirt an file. Le gach duine agaibh deirim, i seanteanga na tíre seo, 'Céad míle fáilte'.

As well as being a great privilege it is a great pleasure to me, as Head of the Irish Government, to welcome you to this the ninth Congress of the International Astronomical Union. We feel honoured that our capital city should have been selected for the holding of what is not merely the greatest scientific congress ever held in Ireland, but one of the biggest, if not the biggest, Congress of the Astronomical Union ever held in any country.

We feel the more honoured to be your hosts in that, while we are an ancient nation, ours is but a small country with neither the wealth nor the natural resources that might enable us to make a major contribution to modern scientific research. If, however, hospitality and a warm welcome are of any account in the success of such a conference as this, then you may feel assured that in that particular aspect of your proceedings we shall not fail you.

In saying this I am not to be taken as implying that we are quite newcomers to astronomical studies. As a matter of fact we can justly claim to have played some little part in the foundations of your science.

The Irish language was the first vernacular in Western Europe to be used in the service of astronomy. For over a thousand years-in fact, since the fifth centuryour annals have been chronicling solar and lunar eclipses.

Among the symposia listed for the present conference there is one on the comparison of the large-scale structure of our galaxy with that of other stellar systems, and you will pardon me if in this regard I recall the name of an Irishman. It was William Parsons who, by means of what was in his time the largest telescope in the world, discovered a century ago the spiral nature of the nebulae or 'island universes' which fill space and which it is your privilege to study. 
The name of Rowan Hamilton will also be familiar to you. For long it was regarded as a paradox that this eminent Professor of Astronomy (he had been appointed to the post while still an undergraduate) should have appeared to neglect the subject which provided him with a means of livelihood-a not altogether unimportant consideration, even for scientists - and to have devoted his genius entirely to mathematics. But with the stupendous advances in scientific knowledge that have since taken place, the wheel has come full circle. Hamilton's work on dynamics has, as you are aware, in our own day proved of great value, both directly and indirectly, to astronomers, for it lies at the root of wave mechanics, a subject fundamental for the understanding of atomic structure and so one with which every astrophysicist must be familiar.

Dunsink Observatory is approaching its second centenary, is one of the oldest observatories in the world, and so has a certain claim upon your veneration.

However, it was not your purpose in coming here to be lectured even on such a small part of the history of Ireland. I have mentioned these points merely to emphasize that, as illustrated by Hamilton's discoveries, science, like peace, is indivisible. In our day, it is coming more and more to be seen that in the search for truth all branches of knowledge converge.

With our finite intellects we cannot hope to attain in this world to the Ultimate Truth, but, to the lay mind at least, if there is one branch of science to which the search for truth is peculiarly appropriate, that branch is your own subject, for the astronomer, of whatever race or nation, is not so much concerned with our petty mundane affairs as with the whole universe, indeed, with a universe of universes stretching to the uttermost bounds of human ken. The astronomer's eye, like that of the poet, rolls 'from heaven to earth, from earth to heaven'.

We laymen would therefore expect that metaphorically as well as literally your vision should range far above the petty trials and tribulations of the everyday world, and with this in mind I feel that it is a happy occasion which brings together in friendly rivalry and with peaceful intent the delegates from some forty-one nations who comprise the present assembly.

Today as never before the scientist is entitled to say of himself, 'in nature's infinite book of secrecy a little can I read'. But even that little he can read has brought home to the human race more forcibly than ever before the terrible truth that confronted man in the day of his creation, that the fruit of the tree of knowledge is both good and evil. During my own youth it was the fashion among some of the camp followers of science to promise mankind the millennium, but man's misuse of the power he has acquired over nature has brought a sad disillusion. Not heaven upon earth, but something more in the shape of a hell upon earth would seem to be in store for us if we continue to turn to evil purposes the mighty weapons that science has put into our hands.

May I, as the head of the government of a small nation vitally interested in the peace of the world, venture to hope that, like the recent world conference of nuclear physicists at Geneva, the present Congress will be a milestone on the road back from the abyss into which the world has for many years been gazing with horror, and that your assembly will be successful in its attempt to extend the frontiers of knowledge, and at the same time be a solid contribution towards international peace and goodwill.

Would I be accused of levity by this grave assembly were I to recall that it was Dublin's 'Paycock' who asked himself the questions- 'What is the stars-what is the stars?' 'What is the moon? '-and to express the hope that the delegates at this historic congress will materially assist in the answer to those pertinent questions.

We like to think that we are a generous and warmhearted people. On behalf of that people I wish that God may speed and prosper your work and I bid you céad mile fáilte, an Irish phrase which, translated into small astronomical figures, means 'Welcome multiplied by ten to the power of five'.

I have great pleasure in declaring this conference open. 


\section{A Thaoisigh, is a Dhaoine Uaisle,}

I am very happy to join in bidding you welcome. As you have been told we are all pleased that you have favoured our country by selecting it for this Assembly. We hope you will find this old city a congenial setting for your discussions, and in the visits you may pay to our countryside that you will find rest and enjoyment.

Those whose work lies in fields in which the unpredictable, devious will of Man is dominant, envy you men of science the relative stability of that on which you work. All can, however, with profit, copy your example of ready co-operation, and learn the lesson which you teach, that generous sharing is the true road to riches. In succinct Irish phrase-'An té de bheir is é do gheibh'. Once more I welcome you.

Cuirim céad míle fáilte romhaibh. Tá súil agam go mbeidh toradh maith ar bhur saothar. Is é ár nguí go ndéanfaidh na habhal-iontais ar a mbíonn sibh ag déanamh staidér agus machtnaimh, go ndéanfaidh siad an chine daonna a stiúradh chun aithne choir a chur ar an Té is fíor-thús agus críoch dheireannach do gach uile ní dá bhfuil ann.

\section{Translation of the paragraph in Irish}

I bid you a hundred thousand welcomes. I hope that your labours will be fruitful. It is our prayer that the marvels which you study and contemplate may lead mankind towards a just knowledge of Him Who is the true beginning and the final end of all that is.

\section{Address by Rt Rev. Mgr Dr P. DE BRÚN}

A Chathaoirligh, a Thaoisigh agus a thoscairí oirdhearca na coigríche agus THír ÉIREANN, AGUS a RÉALTóirí AN DOMHAIN UILE:

Pribhlêid agus onóir domsa thar áireamh agus thar réasún, mé bheith ag fógairt fáilte go hÉirinn roimh réaltóirí na cruinne; thar áireamh, mar ná fuil teora le niamh na heolaíochta so atá lena mílte blian d'iarraidh chruaicheisteanna spéartha an Uilechomhachtaigh a réiteach, agus mar gheall ar abaltacht agus ard-éirim an lucht léinn atá bailithe im thimpeall, agus thar réasún, do bhrí ná fuil ionamsa ach duine d'iarraidh a longe eolas éigin d'fháil as a n-oibreacha.

Ach tuigtear dom go bhféadaim dhá chúis a thabhairt go n-oireann do Chumann Eadarnáisiúnta na Réaltóirí teacht i mbliana go hÉirinn, ceann acu ag baint le seanscolaíocht na tíre, agus ceann eile lena nua-scolaíocht. An chéad cheann gur i scoileanna na tíre seo sa naoú céad, le linn aoiseanna dorcha na hEoraipe, a tugadh ar an saol ar dtúis an córas gréine is pláineadaí is gnáthach a luadh le Tycho Brahé; tá sé le fáil i leabhar Eireannaigh den naoú céad, an leabhar De Divisione Naturae atá ar scríbhinní Johannes Scotus Eriugena. Agus léirionn sé sa leabhar chéanna, mar phrinsiobal eigeantach chlaoí na cruinne le chéile, sú-tharraig an uile phairteagail ábhair chun an uile phairteagail eile.

An dara cúis díobh, ní gá dhom ach aon ainm amháin a lua, ainm duine a bhfuil a chuid saothair ina bhonn fén optic nua, fén dynamic nua, fén réaltóireacht nua. Ar na fearaibh cáiliúla a chuaidh roimh an Ollamh Brück i mbun Réaltfhaire Dhún Sionca do bhí William Rowan Hamilton. Ní beag san.

Mr Chairman, Your Excellencies, representatives of Foreign lands and of IRELAND, AND ASTRONOMERS OF THE WORLD:

It is for me a privilege and an honour beyond reckoning and beyond reason to welcome to Ireland astronomers from all places under the Sun; beyond reckoning, because there is no bound to the splendour of the science that has been seeking for thousands of years to solve the difficult problems of the skies of the Almighty, and also because of the high aim and ability of the learned assembly gathered round me: and beyond reason, because I am only one who seeks a longe to win scraps of knowledge from their works. 
But it seems to me that I can give two causes why it is fitting that the International Astronomical Union should visit Ireland this year, one of them related to the ancient schooling of Ireland, and the other to its modern schooling. The first of these causes is that it was in the schools of this country in the ninth century, during Europe's Dark Ages, there was brought into being the system of Sun and planets generally associated with Tycho Brahé; it is to be found in a book by an Irishman of the ninth century, the work De Divisione Naturae of Johannes Scotus Eriugena. And in the same book he expounds as the compelling principle of the holding together of the universe, the attraction of every particle of matter by every other one.

For the second of these causes, I need only mention the name of a man whose work is fundamental in modern optics, in modern dynamics, in modern astronomy. Among the renowned men who preceded Prof. Brück in charge of Dunsink Observatory, there was William Rowan Hamilton. That is enough.

\section{Address by Prof. H. A. BRÜck}

A Thaoisigh, Your Excellencies, Ministers, Mr President, My dear Colleagues, LADIES AND GENTLEMEN,

It is both a very great honour and a sincerely felt pleasure to me to be able to welcome you here in Dublin on behalf of the Irish scientists and of the Irish astronomers in particular. When, at the Rome Assembly, I had the privilege of issuing an invitation on behalf of Ireland to the members of the Union to hold their ninth Assembly here in Dublin, I little realized that you would respond as generously to our invitation as you have done.

From my latest information, more than 600 astronomers from forty-one countries in all five continents are gathered here, a record attendance in the history of the Union, and the most representative meeting it has ever had. We are very pleased that so many of you have found it possible to bring your wives and families with you, and we hope that they all will have an enjoyable week while their husbands are at work.

I should like to extend a particular welcome to those delegates who have come from distant countries overseas-Africa, the Americas, Asia and Australia. There are quite a number here today who have travelled practically half-way round the globe to attend this meeting.

Nearly a quarter of this Assembly is made up of astronomers from the United States. This will be a particular joy to Irish people, who have always had such close ties with that country, the one with the greatest Irish population in the world. In the second largest group, that of the British astronomers, we are meeting again many friends of whom we here retain very pleasant memories from the Dublin meeting of the Royal Astronomical Society in I950, the very first meeting of that society to be held outside Great Britain.

We are most happy to welcome, too, such large numbers of astronomers from almost every country on the continent of Europe, and from as far away as Russia.

This Union has always been proud of its truly international character and has always jealously guarded the spirit of supranational scientific co-operation. It is encouraging to see how, in this year, at the Geneva Conference on Nuclear Energy, that same spirit of friendly co-operation, without which progress in astronomy would be unthinkable, has descended from the stars to atoms. Here in Dublin we are indeed hoping that astronomers from all over the world will be able to say, when the week is over, that their discussions have been fruitful and their journey worth while.

We wish you all, therefore, a very happy and successful week among us. The fact that the Taoiseach, the Ministers of State, the highest dignitaries in the land, and the whole Diplomatic Corps, led by His Excellency the Apostolic Nuncio, are attending here this morning, will show you how much your coming to Ireland is appreciated. We trust that the friendliness of the reception which, I have no doubt, you will receive from everyone will make amends for some of the inconveniences which you may possibly encounter. We 
ask you to remember that Ireland is a small country and that Dublin, though of recent years quite used to conferences, has never in its history experienced an international scientific gathering of this magnitude. We are only a few people here, who have organized this meeting, and we must ask for your indulgence if you find anything amiss.

All previous Assemblies of the Union have taken place in cities with great and flourishing astronomical institutions of long-standing repute. In the case of this Assembly, we Irish astronomers must regard it more as a ceremony of inauguration, since today's astronomy in Dublin is only of very recent origin. Though the history of the Dunsink Observatory dates back some I70 years, to the time when it was founded by Trinity College, Dublin, its continuity was sadly interrupted in the twenties of this century. The present institution was opened only a few years ago and is now operated and sustained by the generosity of the Irish Government. Perhaps you will allow me to pay here a tribute also to $\mathrm{Mr}$ de Valéra, whose personal interest in all scientific matters was responsible originally for the reopening of the Observatory.

As you know, one of the Symposia of this Assembly to which we are all looking forward, will be concerned with galaxies. If our Union had been in existence a century ago, the choice of Ireland would indeed have been most fitting for a discussion on this subject. It was the time when the third Earl of Rosse built in Birr, right in the centre of the country and with local resources only, his justly famous 72-inch telescope. As the Taoiseach has told you already, this was an instrument which for many years remained the world's largest telescope, and which was put to such excellent use in the study of the nebulae. As you all know, Lord Rosse was the very first to discover the spiral structure of such nebulae as $\mathrm{M}_{5} \mathrm{I}$, and his fine and detailed drawings of this whirlpool nebula, for instance, which are still preserved in Birr, are all the more astonishing when one considers the many disadvantages under which he had to labour.

A huridred years ago Ireland was indeed in the forefront of observational astronomy. It held its own no less in the field of theoretical research. On a visit to Dunsink Observatory, the astronomers of roo years ago would have been received by William Rowan Hamilton, one of the great mathematicians of his day, whose work in dynamics and optics has retained its vitality up to the present time.

I will not trouble you with many other names of Irish astronomers well known in their day. It may be worth while mentioning, however, that when you speak of a nebula as NGC 4594 you use a catalogue compiled by another astronomer of Ireland, Dreyer, who first worked at Dunsink to become later a distinguished astronomer at Armagh Observatory, where he gave us also some scholarly treatises on the history of astronomy.

The older days have at least one link with the present, in the work of $\mathrm{H}$. C. Plummer. His name may mean little to the younger generation of you here, but Plummer was in fact responsible for some painstaking studies of variable stars, in the course of which he proposed, in I9I4, and independently of Shapley, the then completely novel hypothesis of radial pulsations.

Plummer's theoretical work was based on his own observations with the I5-inch reflector at Dunsink, which has been only recently replaced by a larger instrument.

Plummer was the last in line of nine astronomers who had worked at Dunsink over a period of 150 years, a period which had not been without distinction. However, by and by the equipment had become completely out of date, and when the observatory was reopened, an altogether fresh start was necessary, so that little remains now of the original institution.

An astronomer trying to set up an observatory in Ireland finds himself faced by twc major disadvantages: the first, a local one, is the traditionally erratic Irish weather, of which, I hope, you will have little experience during the coming week; the second, equally grave, and probably more universal, is a certain lack of funds! As you know best, observational astronomy can be an expensive field, and a small country such as this can hardly be expected to indulge in too much of it.

A radio-telescope would have overcome the disadvantage of the weather, but its construction proved impracticable, unfortunately. An installation for solar research 
appeared to be a possible alternative. In solar spectroscopy, a little sunshine can be made to go a long way; a few minutes' observation can provide material for weeks of reduction when the rain pours down all day. And that the Sun occasionally does shine here, you are fortunate enough to be able to verify this morning. We are probably experiencing already the happy result of a magic spell cast by your Congress Badge, an old Irish symbol of the Sun, which at the same time shows you that the Sun was definitely visible to the Irish of 3000 years ago.

We have set up in the observatory, therefore, what appears to us quite an effective solar installation, with facilities for spectrographic and spectrohelioscopic observations. I hope that during your stay here you will experience also something of the extraordinary clarity of the Irish sky as we get it after a period of rain, a transparency which is often coupled with image definition well above average. Such conditions suggest strongly photometric work, and we have concentrated, therefore, on developing electronic methods of photometry, testing these in the case of stellar photometry with a new medium-sized reflector.

It is, of course, impossible, in the Irish climate, to undertake programmes which require continuous observation, and it has been extremely fortunate for us that we have been able to secure a share in a large Schmidt telescope in Bloemfontein, South Africa. There we can hope to secure observational data of real importance for research on galactic structure. The Armagh-Dunsink-Harvard telescope represents, also, a concrete expression of the close ties that exist between astronomers in Ireland, north and south, at Armagh and Dunsink. I am happy to know that many of you will have an opportunity of visiting Armagh when this Assembly is over.

I also recall your attention to the fact that when, in 1947, the observatories of Armagh, Dunsink and Harvard joined forces in acquiring the Armagh-Dunsink-Harvard telescope, it was, I believe, the first instance of international ownership in astronomy. It is pleasing to know that the international character of the original arrangement has now been widened further so as to include the operation of the whole Boyden Station by a sixnation council. We hope that some of the experience gained in this experiment may prove useful to the proposed foundation of a great European observatory in South Africa, a scheme which would be of immense value to astronomy.

At the end of my talk I should just like to express the hope that few of you will leave Ireland without doing us the honour of visiting Dunsink Observatory some time during the Congress week, and let me once again wish you all a successful Congress astronomically and a happy week in Dublin among the Irish people.

J'espère ne pas vous avoir trop fatigués par un discours trop long en anglais. J'ai essayé de vous donner une idée de l'état de l'astronomie en Irlande, de certains de ses résultats acquis dans le passé et de notre travail actuel. En ce qui regarde Dunsink, bien qu'elle existe depuis cent soixante-dix années, sa disposition actuelle est de récente date. J'espère que vous nous ferez tous l'honneur de visiter l'Observatoire pendant la semaine du Congrès. Je suis heureux d'apprendre que plusieurs d'entre vous visiteront nos collègues de l'Observatoire d'Armagh avec qui nous avons des relations très amicales dont le Télescope Armagh-Dunsink-Harvard à la station Bloemfontein est le symbole.

Avec la présence ici de plus de six cents astronomes représentant 4I pays cette Assemblée est non seulement la plus nombreuse dans l'histoire de l'Union Astronomique Internationale mais aussi le plus grand congrès scientifique qui s'est jamais réuni en Irlande.

Vous avez entendu de la bouche des représentants d'Irlande, plus autorisés que moi, combien votre présence ici est appréciée. Je suis certain que vous serez tous les bienvenus partout en Irlande et, que l'accueil que l'Irlande vous réserve compensera les inconvenients qu'entraîne nécessairement l'organisation d'un congrès si immense avec des ressources assez maigres.

Nous vous souhaitons cordialement à tous un séjour agréable parmi nous et nous espérons qu'au point de vue scientifique ce séjour n'aura pas été en vain. 


\section{Address by Prof. O. STRUve}

We have met in many different countries: Italy in I922, England in r925, Holland in 1928, the United States in 1932, France in 1935, Sweden in 1938, Switzerland in I948, and again in Italy in 1952. Now we have come, for the first time, to the Republic of Ireland-and we are grateful to the Government, to the two great universities of Dublin, and to the Dunsink Observatory for having extended to us their hospitality. We have a larger attendance here than we have had at any previous meeting, and we look forward to a week of absorbing interest for all of us.

My own acquaintance with Ireland goes back only a little more than nine years. But I made that acquaintance in the service of the I.A.U. You will recall that soon after the end of the war Sir Harold Spencer Jones and Dr J. H. Oort decided to hold a meeting of the executive committee in Copenhagen and invited a number of astronomers who were not members of the committee. And so, on a stormy morning in March I946, Harlow Shapley, Joel Stebbins and I alighted at the Shannon airport from a transatlantic plane. Shannon was not then, as it is now, the daily meeting-place of thousands of travellers. Yet, to our surprise, the waiting room was crowded with people. As we were waiting for the announcement that our flight was ready to proceed, Dr Stebbins called my attention to a distinguished-appearing gentleman who was sitting across the room. I saw a face that seemed strikingly familiar, yet I could not identify it. So we called an attendant and asked him. The boy seemed surprised and slightly impatient at our ignorance. 'You don't know?' he said. 'That is the one and only Dev!' To us Americans this was the finest demonstration of Irish democracy we could have had. Dr Shapley, who is always interested in the international aspects of astronomy and who, at this particular time, was engaged in planning a joint observatory in Africa with the participation of Armagh, Dunsink and Harvard, asked the boy whether he could speak with Mr de Valéra. 'Of course,' replied the boy, 'in our country anyone speaks to the Prime Minister!'

Mr de Valéra was at the airport to receive the American cardinals who were returning home from a trip to the Vatican. Bad weather had delayed their plane, and it forced us to remain in Ireland for twenty-four hours. We spent the night in a small hotel, the Blue Boar, in Tipperary - a name known to me from the words of the popular song, 'It's a long. long way to Tipperary'.

Many in this audience are attending for the first time a meeting of the I.A.U. Few of those in attendance were present when the Union was founded in Brussels in I9I9I know of only one: Prof. F. J. M. Stratton. I believe that only three, Prof. Giorgio Abetti, of Italy, Prof. Shapley, of the United States, and Prof. Stratton, of Great Britain, have attended all general assemblies up to that in Rome three years ago. It may, therefore, be useful to review the aims of the Union before we start our activities this afternoon.

The purpose of the Union is stated in Article I of the statutes, as follows:

(i) to facilitate the relations between astronomers of different countries where international co-operation is necessary or useful;

(ii) to promote the study of astronomy in all its departments.

With these broad principles we are as much in accord today as were our founders thirty-six years ago. But from time to time there is a need to re-examine these cornerstones of our organization, and to seek new ways to implement them. It is the duty and the privilege of the president to give attention to these matters, and most of my predecessors have done so in one form or another. In his opening address to the Union at its first meeting in Rome, in I922, President Benjamin Baillaud interpreted the purpose of the Union in these simple words: 'La recherche astronomique est l'objet essentiel de notre Union.' And he added:

Ce sont toujours les plus grands instruments, disaient Paul et Prosper Henry qui ont donné les dernières découvertes en astronomie. La formule est peut-être un peu excessive. Cependant, un peu modifiée, elle devient: les plus grands instruments permettent de faire ce 
que ne permettent pas les autres. Il y a là une nouvelle révolution: après l'invention des lunettes, de la spectroscopie, de la photographie, voici venir les instruments géants, qui doivent être des chefs d'œuvre de mécanique et d'optique, établis dans les sîtes les plus favorables à tous égards. . . . La vie de l'astronome continuera certes à être austère; mais combien n'est-elle pas séduisante par l'immensité des problèmes à résoudre et la certitude d'y récolter une riche moisson. Peu de sciences font autant d'honneur à l'humanité.

Three years later, at the University of Cambridge, W. W. Campbell returned to this subject in the following words:

Those of us who were privileged to take part in the organization of the International Astronomical Union, at Brussels six years ago, will remember that unusual care was exercised in defining the purposes and function of the Union. It was not to be a society, international in scope, to provide the opportunity for the reading of papers describing work already done and results already obtained. Some of us recalled that several societies, more or less international in constitution, representing astronomy and other sciences, had long existed, and that they did not attract attendance from beyond the oceans in appreciable numbers. A study of the subject led us to the conclusion-a conclusion doubtless reached earlier by othersthat national societies with principal functions the reading and discussion of papers relating to researches conducted by individuals meet a definite need, and in many cases are splendidly successful, but that societies international in character, to command attendance and success, must have other and broader aims, more general and more impelling purposes.

It is to be noted, in Article (I) [of the constitution], that the motive is 'international co-operation when necessary or useful'. The words necessary and useful have been chosen with care. The article does not say international co-operation whenever possible, nor does it encourage a search for problems to the solution of which international co-operation could be applied. Whether we are looking for technical results of great value, or for the improvement of relations between the peoples concerned, international co-operation, to be justified, should have such impelling motives as to give clear promise of usefulness and success.

... experienced astronomers recalled the fact that the great advances in the several sciences have been the results of developments and discoveries made by individuals, and that this principle will always hold true; and, further, that the Union then in process of organization should never be in a position to interfere with individual initiative. . . The purposes of the Union refer to future developments, rather than to a recital of the accomplishments of the past.

Equally instructive are the following words of W. de Sitter, who presided at the Leiden meeting in r928:

Science is international by necessity and by choice, and astronomy, the oldest of the sciences, has perhaps more need of international co-operation than any other science, and also has always been in the front ranks of those who are seeking international organization. . . .

Astronomy is a science that must be served for its own sake, or not at all. It is, one might say, a useless science, as it has no practical applications worth speaking of, and the little practical knowledge of astronomy that is required for those few applications that it has is easily acquired by anybody. As Poincare has so beautifully expressed it: it is not science that is useful because its discoveries make technical progress possible, but technical progress is useful because it enables mankind, by relieving it of material cares, to give more time to science and to art. ... I will . . . accept the extreme consequences of Poincaré's point of view and say that even by its utter uselessness astronomy is the most beneficial of all sciences for serving the ideal aims of mankind.

And, finally, I quote from Sir Frank Dyson's speech at the Harvard meeting of the Union in I932:

We believe, as the Secretary of the Navy has said, that astronomy is very important for navigation and for the world. In astronomy, as in science generally, we are building on the work of our predecessors; and one never knows what will be discovered, perhaps something 
quite unexpected. Nothing has appealed to the popular imagination more than the Einstein discovery of relativity. There is much to learn, possibly something to correct. It is our business to follow Herschel's maxim-'Whatever shines must be observed'.

The highlights of these earlier interpretations of the activities of the Union may be summarized as follows:

There was Baillaud's insistence upon the supreme importance of great telescopes.

There was Campbell's warning that we should engage only in those activities which really require international co-operation, and that we should never interfere with the individual initiative of great minds.

There was de Sitter's emphasis upon the fact that the apparent uselessness of astronomy renders it the most beneficial of all sciences in serving the ideal aims of mankind, and there was Dyson's quotation from Herschel that whatever shines must be observed.

If we are to reinterpret our function at the present time, we must, I believe, focus attention upon those changes that have taken place in astronomy, and in science in general, during the past few decades. This can be done in several ways, but I thought it would be most instructive to turn back the pages of history and to compare the achievements of our predecessors with those made by ourselves and our contemporaries. And while our time scale is an arbitrary one, based upon the accidental length of the period of the earth's orbital motion around the Sun, let us ask ourselves: What was astronomy like roo years ago?

I find in a treatise on the history of science the following entry for the year 1853: 'Lectures on Quaternions-As great an advance over analytical geometry as the latter was over Euclidean geometry.' And who was the author of these lectures? Sir William Hamilton, whose bust graces the main room of the famous library of Trinity College in Dublin, and who in 1827 , at the age of 22, was appointed to the position at the Dunsink Observatory that is now being filled by our host, Prof. H. A. Brück. Sir Robert Ball, also a director of this observatory, wrote in I892: 'The history of Dunsink Observatory for the next 38 years [after Hamilton's appointment at Dunsink Observatory] may be epitomized in a single word-Quaternions.' Some of us may not have had occasion to use this remarkable extension of vector calculus, but no astronomer in this room has failed to study Hamilton's method of dynamics!

William Rowan Hamilton was born on 4 August I805, at No. 36 Dominick Street, Dublin. A remarkable child, at the age of 3 he could read English and make advanced arithmetical calculations. At $I_{7}$ he visited John Brinkley at the observatory and discussed with him two papers, entitled 'Osculating parabola to curves of double curvature and surfaces' and 'On contacts between algebraic curves and surfaces'.

But Hamilton's great work on quaternions was not the only important advance of Ioo years ago. In I854 Helmholtz, in Germany, announced his gravitational theory of the origin of solar energy. While we no longer believe that the contraction of the Sun is responsible for its light and heat, this theory has become important again in recent years in our discussions of the early stages of stellar evolution.

Also in 1854 Pogson, in England, standardized the ratio of the brightnesses of stars of different apparent magnitudes and thereby introduced into astronomy the ratio that bears his name. Two years later Steinheil, in Germany, and Foucault, in France, independently invented the silvering process for astronomical mirrors.

But I believe that if we are to choose a purely astronomical event of overwhelming importance, whose hundredth anniversary we may rightly celebrate today, it is the monumental work of Argelander which culminated in the Bonner Durchmusterung. The year I855 is probably better known to astronomers than any other. We have all been called upon to compute the precessions of the stars from the standard epoch of the Bonn zones!

Argelander wrote in the third volume of the Astronomische Beobachtungen auf der Sternwarte $z u$ Bonn that the observations of more than 300,000 stars were started in 
I852 with a Fraunhofer comet seeker 3 in. in aperture and 24 in. in focal length. The observations were continued by Argelander, Schoenfeld and Krueger.

It is of interest to note that the I.A.U. at the Zürich meeting in 1948 recommended that a new edition of the charts of the $B . D$. be produced by the Bonn Observatory. Dr Friedrich Becker, the present director of the Bonn Observatory, is to be congratulated upon having carried out this important task.

These examples suffice to illustrate the tremendous change that has taken place in astronomy. One hundred years ago the most important advances were made by single men of genius, in this case by Hamilton and Helmholtz, working alone in the privacy of their 'ivory towers', and by a few able observers (Argelander, Schoenfeld and Krueger) using small telescopes at a single observatory. At the present time the emphasis is upon teamwork and upon the use of very large and expensive instruments at many observatories.

It is an intriguing question to decide whether this emphasis upon teamwork has deprived the world of individual thinkers like Hamilton and Helmholtz, but no one will deny that their numbers have not increased as rapidly as has the number of more or less anonymous scientific workers whose results now account for the major share of scientific production. We might well ask ourselves whether we are doing enough by following Campbell's advice of not interfering with individual initiative. Perhaps we should more actively encourage such initiative and accord it proper recognition in our union by providing for a kind of membership that does not require the pigeon-hole of a commission. I remember several occasions in the past when an eminent astronomer could not become a member of the Union because there was no suitable pigeon-hole for him. Our only solution of the resulting dilemma was to create, artificially, a new commission in order to accommodate such a person.

Nevertheless, the great majority of our members are team workers, and for them the present structure of the Union is reasonably satisfactory. We should recognize at once that we have already departed to a large extent from Campbell's idea that the Union should be concerned with future developments and not with the recital of accomplishments of the past. We have found by experience that the symposia, which, in effect, do consist of such recitals, form a necessary basis upon which to build our plans for the future. At the same time, let us not lose sight of the fact that our principal purpose remains, as before, the planning of astronomy in all its aspects. This we are already doing at our meetings, but I believe we are doing it unconsciously rather than as the result of a well-directed effort. And I am afraid we are doing it on a timid and haphazard scale.

Let me read to you two excerpts from a study inspired in I9I9 by George Ellery Hale. The first is by Elihu Root, a former board chairman, Carnegie Institution of Washington, a Secretary of War and of State in the Cabinet of Theodore Roosevelt, and a close associate of Woodrow Wilson in the Paris peace negotiations. He wrote:

Science has been arranging, classifying, methodizing, simplifying everything except itself. It has made possible the tremendous modern development of the power of organization which has so multiplied the effective power of human effort as to make the differences from the past seem to be of kind rather than of degree. It has organized itself very imperfectly. Scientific men are only recently realizing that the principles which apply to success on a large scale in transportation and manufacture and general staff work apply to them; that the difference between a mob and an army does not depend upon occupation or purpose but upon human nature; that the effective power of a great number of scientific men may be increased by organization just as the effective power of a great number of labourers may be increased by military discipline.

The second quotation is from the writings of Henry S. Pritchett, formerly president of the Carnegie Foundation for the Advancement of Teaching:

The world still conceives of scientific investigators in much the same light as the old time prospectors for the precious metals-each individual sinking his shaft here or there as chance 
or inclination may carry him. Of the great number so engaged a very few will strike veins of true gold, a larger number will obtain ore that will at least repay the labour and cost involved in their adventure, but the great majority will sink holes in barren and fruitless soil.

These are strong words, and they will arouse in many minds the thought of regimentation. Can we increase and improve our planning activities and at the same time stimulate the individual astronomer to bring out his best and original effort? Fortunately, the I.A.U. possesses no powers of any kind. It can act only in an advisory capacity. Its funds are so limited that it cannot even bring the strength of money to bear upon the enforcement of its views. I am, therefore, not fearful of regimentation. The Union could and should act as the supreme counselling centre for all astronomers who request advice. It should also go beyond this and make specific recommendations through the various national committees to their respective governments, and it should formulate and constantly revise a general plan for developing astronomy in all its aspects.

How can this task be accomplished? As a believer in evolution rather than revolution, I do not advocate sudden changes. But it seems to me that the president, who has little to do between meetings, and the vice-presidents, who have even fewer assignments, could constitute themselves as an informal committee and prepare appropriate statements for presentation at our general assemblies. As a first step in this direction, I suggest:

That the national delegations represented at this meeting take home with them certain recommendations for consideration by their national committees and for possible presentation to their appropriate government agencies;

That these same recommendations be mailed to the national committees of those member countries that are not represented here;

That they be also communicated to such scientific organizations as national academies, research councils, professional societies or even government agencies in countries that do not claim membership in the Union.

My recommendations are as follows:

I. Astronomy is international in character and requires the active participation of all civilized nations. The I.A.U. solicits the adherence of all countries that are interested in research. It now has a membership of thirty-six nations, and several new applications are pending at this meeting or are in the process of formulation.

2. Astronomy is also global in extent, and many of its most pressing problems can only be solved by means of observations distributed over the entire surface of the earth.

3. Astronomy is, as de Sitter has said, 'the most beneficial of all sciences' because it uplifts the minds of all people and, more than any other science, serves 'the ideal aims of mankind'. Just before the outbreak of the Second World War, in I938, Sir Arthur Eddington remarked, in accepting the presidency of the union: '.. if in international politics the sky seems heavy with clouds, such a meeting as this at Stockholm is as when the Sun comes forth from behind the clouds. Here we have formed and renewed bands of friendship which will resist the forces of disruption.'

The success of our Union since the end of the war has shown that ideological and political differences fade away in our common goal, the exploration of the universe. Moreover, astronomy is no longer so 'useless' as it was twenty-seven years ago, largely because of the stimulus it has given to the study of nuclear energy. And in these days of serious consideration of future developments such as an artificial satellite of the earth, and even space travel, it promises to become one of the useful sciences in a practical sense.

4. There has been a disquieting increase in the disparity of astronomical effort in the various countries. One hundred years ago some of the most important advances were made in small and poor countries. Today this is rarely the case. Those countries which were greatly disturbed by the recent wars have of necessity come to appreciate to a greater extent the importance of basic science than have those countries that experienced lesser upheavals. The support of basic science is a small item in any national budget. Perhaps it should be kept at a reasonable level in order to provide for the necessary 
uniformity of geographical distribution of astronomical research. In the United States the annual expenditure on astronomy between 1923 and 1948 was of the order of $\$ 1,500,000$ per year. At the present time this figure should be more than doubled. The National Science Foundation spends about $\$ 200,000$ annually for small research projects by individual investigators. It plans to spend several million dollars a year for larger enterprises such as a new national observatory, several large radio telescopes, and several large electronic computing centres.

5. The most important tools of astronomy are the astronomers. Their training should be the first concern in all countries. To a small extent the I.A.U. has helped-and is ready to help - in this task through its commission on the exchange of astronomers, under Prof. Stratton. A special effort should be made to induce persons of great ability to enter the field of astronomy, and individual workers of the 'ivory-tower' variety should be encouraged. Countries that have not yet developed astronomical research to any great extent can avoid many of the difficult steps by providing opportunities for their citizens to study in large institutions abroad. Most national governments encourage foreigners to visit their institutions and give them opportunities to profit from the experience of existing organizations.

6. The importance of large telescopes, already stressed by Baillaud in I922, has still further increased. There is urgent need for a greatly increased flow of basic information. Any astronomer can think of dozens of programmes of observation-for example, the continuous spectroscopic and photometric survey of rapidly evolving binary stars like Beta Lyrae - that cannot now be carried on with existing telescopes. We may safely assume that the flow of recorded facts needs to be increased by a factor of Io, and the number of large telescopes by a corresponding factor, if we are to provide the information that is required for theoretical studies. No one needs to fear that the 200-inch Hale reflector will solve all remaining problems.

7. There must be diversity in the construction of telescopes. Countries that have poor climatic conditions might concentrate upon radio telescopes, while others with good daytime seeing might emphasize solar research.

The executive committee of the I.A.U. stands ready at any time to furnish advice on these subjects. 